\title{
Pesticide residues analysis in farm gate vegetables of agricultural areas in Tumakuru district, Karnataka, India
}

\author{
B. S. Shylesha \\ Department of Chemistry, Sree Siddaganga College of Arts, Science and Commerce, \\ Tumakuru - 572102 (Karnataka), India \\ Mahesh. M. \\ Department of Biotechnology, Azyme Biosciences Private Limited, Bengaluru - 560069 \\ (Karnataka), India \\ V. N. Yoganandamurthy* \\ Department of Biotechnology, Azyme Biosciences Private Limited, Bengaluru - 560069 \\ (Karnataka), India \\ "Corresponding author. E mail: dryoganand16@gmail.com
}

\section{Article Info}

https://doi.org/10.31018/ jans.v13i4.2879

Received: August 3, 2021

Revised: November 27, 2021

Accepted: December 4, 2021

\section{How to Cite}

Shylesha, B.S. et al. (2021). Pesticide residues analysis in farm gate vegetables of agricultural areas in Tumakuru district, Karnataka, India. Journal of Applied and Natural Science, 13(4), 1437 - 1444. https://doi.org/10.31018/jans.v13i4.2879

\begin{abstract}
The main purpose of this experiment was to understand pesticide residues persistence and their toxicity level in vegetables. In the present study pesticide residues in tomato (Solanum lycopersicum) and capsicum (Capsium annuum L.) vegetables cultivated in Tumakuru, Gubbi, Kunigal and Pavagada taluks in Tumkur district were analysed. In methodology, samples of $1 \mathrm{~kg}$ each were collected, cut into small pieces, macerated in a grinder and used for the analysis. Pesticides were quantified by gas chromatography-mass spectrometry (GC-MS). Results showed tomato samples of Pavagada recorded acephate $(0.346 \mathrm{mg} / \mathrm{kg})$, dichlorvos $(0.189 \mathrm{mg} / \mathrm{kg})$, fenvalerate $(0.057 \mathrm{mg} / \mathrm{kg})$ and Tumakuru samples recorded phorate $(0.072 \mathrm{mg} / \mathrm{kg})$ residues higher than MRLs (Maximum residue levels). Chlorpyrifos, cyhalothrin-g and cypermethrin were below detection level (BDL) in all the samples. Cyfluthrin- $\beta$ recorded highest in Kunigal samples $(0.294 \mathrm{mg} / \mathrm{kg})$, Tumakuru and Gubbi samples showed BDL. Deltamethrin was highest in Pavagada $(0.296 \mathrm{mg} / \mathrm{kg})$ samples and Tumakuru and Kunigal samples revealed BDL. Pavagada samples $(0.026 \mathrm{mg} / \mathrm{kg})$ showed monocrotophos residues higher than MRLs. In capsicum samples, acephate residue was highest in Tumakuru samples $(0.333 \mathrm{mg} / \mathrm{kg})$, highest chlorpyrifos $(0.153 \mathrm{mg} / \mathrm{kg})$ in Kunigal samples, deltamethrin $(0.381 \mathrm{mg} /$ $\mathrm{kg})$, fenvalerate $(0.168 \mathrm{mg} / \mathrm{kg})$ and phorate $(0.089 \mathrm{mg} / \mathrm{kg})$ residues were higher than MRLs in Pavagada samples. Cyfluthrin- $\beta$ $(0.045 \mathrm{mg} / \mathrm{kg})$ was high in Tumakuru and dichlorvos $(0.042 \mathrm{mg} / \mathrm{kg})$ high in Pavagada samples. Cyhalothrin-g, cypermethrin and monocrotophos were BDL in all the samples. An attempt has been made to assess the different pesticides usage and their adverse impacts on vegetables, which are backbone to afford assistance for an extensive array of investigators.
\end{abstract}

Keywords: Capsicum, Farmgate vegetables, Gas chromatography-mass spectrometry, Pesticides, Tomato

\section{INTRODUCTION}

Pesticides are widely used throughout the world in agriculture to protect crops. Rampant use of these chemicals has given rise to several adverse effects (Sharma et al., 2019a). Around $51 \%$ of Indian food products are adulterated with pesticide residues and about $20 \%$ of these food products have pesticide residues of maximum residue level (Gill et al., 2020). Low-dose pesticides for elongated duration are progressively more interrelated to human health effects (Wang et al., 2011). Air is polluted due to pesticides and pesticide drift may be seen when the pesticide suspended dust particles are carried by wind to other areas and contaminating them. Due to pesticide application, the crops may volatize and be blown into nearby areas that may threaten wildlife. Indian agriculture is largely traditional oriented and pest management is a built-in process but not a separate activity (Sharma et al., 2014; Yadav et al., 2015). India stands next to China in vegetable production and due to inadequate management and residual toxicity, the development of the export market is causing a prime concern. Farmers choose to provide fruits and vegetables to increasingly large numbers of consumers, recognize particular insects, weeds, nematodes, disease-causing organisms and vertebrates as a competitor that may lower the quality 
and yield of their produce (Abhilash and Singh, 2009; Schreinemachers and Tipraqsa, 2012; Sharma et al., 2019b). Numbers of pesticides have been registered for use in India against various pests and diseases (Thurman et al., 2008). Pesticides can be broadly classified into insecticide, herbicide, fungicide and others. Another classification based on the chemical composition like organophosphates, organochlorines, synthetic pyrethtoids, carbomates, bio-pesticides etc. (Jayaraj et al., 2016). Insecticide use is about $75 \%$ in the country, related to $32 \%$ in the world. Herbicide use only $12 \%$ compared to worldwide ingestion of $47 \%$. Corbomate and synthetic pyrethroids are together used globally (45\%). Organophosphates constitute $50 \%$ of consumption and bio-pesticides used $1 \%$ compared to $12 \%$ worldwide (Schreinemachers et al., 2015; Yadav et al., 2015; Sharma et al., 2019a). Pesticide is essential for adequate food supply to meet the demand of an increasing population and combat the in borne diseases. Fruits and vegetables are an important part of food intake to meet the balanced diet for humans for a healthy life (Bempah and Donkor, 2011; Kostik et al., 2014; Yilmaz, 2015). Indians are mainly vegetarians thereby, consumption of vegetables in their daily diet is maximum (Beena Kumari et al., 2004). Okra, eggplant, tomato, beans, capsicum and cauliflower vegetables are regularly grown because of sound income with less investment to the farmers. In order to increase the yield, quality and to overcome the incidence of insects and pests, farmers use a disproportionate quantity of pesticides, which leads to the contamination of vegetables with pesticide residues (Indira Devi et al., 2017; Beena Kumari, 2008). To improve the growing demand for fruits and vegetables, farmers utilize pesticides to increase production, preventing pests and diseases which cause problems in vegetable and fruit production (Kumar and Reddy, 2017).

Pesticide residues in fruits and vegetables directly result from applications in the crop growing field and, to a lesser extent, from pesticide residues remaining in the soil. Insecticides still account for $70 \%$ of total pesticide use in India and even if the declining trend in use continues, insecticide residues will likely continue to be an issue for another decade (Directorate of Plant Protection, Quarantine and Storage, 2018; Kolani et al., 2016). The majority of the farmers are ill-informed regarding the nature, dose and application of pesticides and their aftermath effects, as pesticides are very hazardous for organisms and human beings (Shammi et al., 2020). Surplus pesticides were entering into water bodies and also come into agricultural fields through wind affecting various species (Velmurugan et al., 2013). Over time, the repeated application increases pest resistance, while its effects on other species can facilitate the pest's resurgence (Damalas and Eleftherohorinos, 2011). Nevertheless, to the best of our knowledge, no research on monitoring of pesticides residues have been reported in vegetables Tomato (Solanum lycopersicum) and Capsicum (Capsium annuum L.) at the field level in four taluks viz., Tumakuru, Gubbi, Kunigal and Pavagada in Tumakuru district of Karnataka State. The present work was aimed to assess the pesticides residues in these two common vegetables tomato and capsicum grown widely in these Taluks.

\section{MATERIALS AND METHODS}

\section{Sample collection}

Two vegetable samples like tomato (Solanum lycopersicum) and capsicum (Capsium annuum L.), were collected from the growing areas of Tumakuru, Gubbi, Kunigal and Pavagada taluks in the Tumakuru district (Fig. 1) during 2019. Six samples each of both tomato and capsicum in each taluk were analysed. Samples were collected according to the international standard guideline (Standardization Administration of China, 2008) and evidence regarding pesticide application to vegetable crops was collected from growers during sampling. Samples of $1 \mathrm{~kg}$ each were cut into small pieces and macerated in a grinder and used for the analysis (Borgert et al., 2003).

\section{Chemicals}

Glass wares used were washed in acetone and dried at $350{ }^{\circ} \mathrm{C}$ in an oven. The required solvents such as n-hexane, acetonitrile, petroleum ether and diethyl ether (HPLC grade) were picked up from Sigma Aldrich Co. AR grade Sodium chloride and anhydrous sodium sulphate was bought from Himedia Pvt. Ltd. India. Acetone is used to refine anhydrous sodium sulphate and heated for $4 \mathrm{hrs}$ at $600{ }^{\circ} \mathrm{C}$ in a muffle furnace in

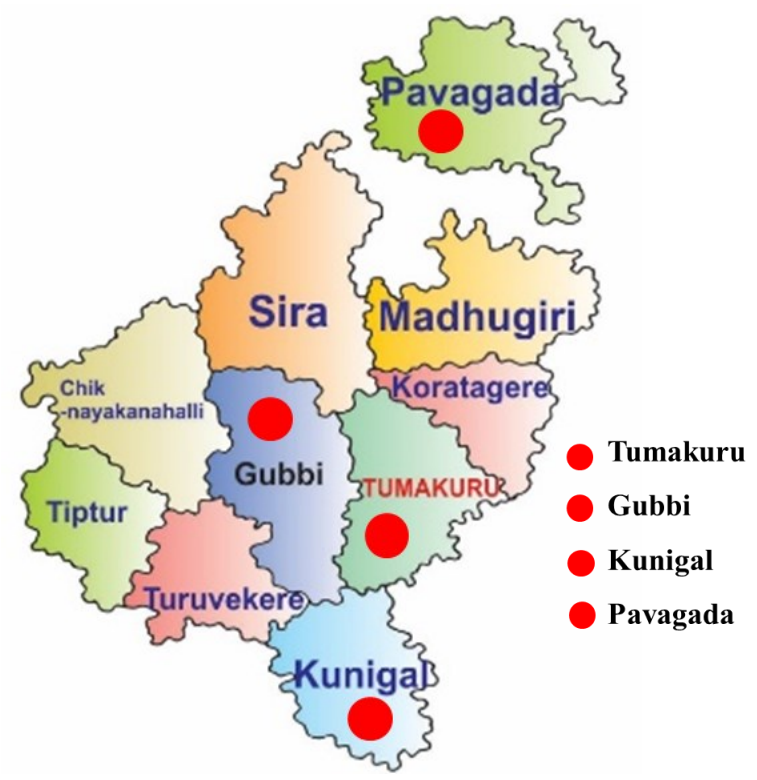

Fig. 1. Tumakuru district map showing study areas 
order to eradicate phthalate scums. Florosil $60-100$ mesh was activated at $350{ }^{\circ} \mathrm{C}$ for $5 \mathrm{hrs}$ before use which is procured from Merck India limited. Pesticide values were procured from the Division of Agricultural Chemicals, Indian Agricultural Research Institute, Delhi, India.

\section{Standard preparation}

Standard methods suggested by Tekel and Hatrik (1996) were followed to analyse the pesticide residues. An exactly weighed $10 \mathrm{mg}$ of a pesticide was liquefied in $10 \mathrm{ml}$ volumetric flask using $\mathrm{n}$-hexane to make the standard stock solution to $1000 \mathrm{mg} \mathrm{kg}^{-1}$. Standard stock solution of each pesticide was successively diluted to get the sudden lower concentration of $100 \mathrm{mg}$ $\mathrm{kg}^{-1}$. Standard stock pesticide solution was prepared by captivating $0.1 \mathrm{ml}$ solution of compatible (acephate, chlorpyrifos, cyfluthrin- $\beta$, cyhalothrin-g, cypermethrin, deltamethrin, dichlorvos (DDVP), fenvalerate, monocrotophos and Phorate) pesticide in a $10 \mathrm{ml}$ volumetric flask, then by using n-hexane volume up to the mark was created and stored in a refrigerator at $5^{\circ} \mathrm{C}$.

\section{Extraction}

Pesticides extraction from vegetable samples was done by EPA $3500 \mathrm{C}$ method (United States Environmental Protection Agency, 2000) and procedure suggested by Di Muccio et al., (2006). Analytically shred the fresh vegetable samples and homogenized. Around $20 \mathrm{~g}$ of sample was softened with $40 \mathrm{ml}$ of ethyl acetate. $5 \mathrm{~g}$ of sodium hydrogen carbonate and $20 \mathrm{~g}$ of anhydrous sodium sulphate was added to confiscate moisture and then macerated for 3 minutes in Ultra-turrax macerator. Samples were centrifuged for $5 \mathrm{~min}$ at $3000 \mathrm{rpm}$ to obtain two phases.

\section{Clean up}

Clean-up step was monitored as described by Fardous et al. (2007) and Rahman et al. (2012) using solid-phase extraction with florisil. The florisil column $(500 \mathrm{mg} / 8 \mathrm{ml})$ cartridge was conditioned with $10 \mathrm{ml}$ ethyl acetate. Pesticides in sample extract $(5 \mathrm{ml})$ were eluted with $10 \mathrm{ml}$ of ethyl acetate; the solutions were concentrated by rotary evaporator to $1 \mathrm{ml}$ and dried by a gentle nitrogen stream, then dissolved in $1 \mathrm{ml}$ of ethyl acetate. Pesticides were then quantified by gas chromatography-mass spectrometry (GC-MS) (Falodun et al., 2009)

\section{Maximum residue limit (MRL)}

Pesticide residues of the present experiment were compared with MRL (Table 1) recognised by European Commission (2012) and Food and Agriculture Organization / World Health Organization (2004). MRL is defined as the pesticide residue level existing in the vegetables. According to Environmental Protection
Agency (EPA), MRL is the pesticide residue concentration present in food merchandise. MRL is the maximum pesticide residue concentration expressed in $\mathrm{mg} / \mathrm{kg}$ recommended by Codex Alimentarius Commission (2017) to be legally permitted in food commodities.

\section{RESULTS AND DISCUSSION}

\section{Harmful effects of pesticides}

Pesticides cause longer-term health impacts for workers and consumers in addition to acute poisoning from field exposures, even people who live around farms. Chlorpyrifos and other organophosphates are harmful to brain function and are associated with preterm births and neurological disorders among people working on farms and living in agricultural areas. Studies have concluded that pesticide is especially dangerous to children (Mnif et al., 2011; Rauh et al., 2015). Other pesticides, like endocrine disruptors, have been linked to low birth weight, abnormal brain development, increased incidence of cancers and reduced fertility among people. Pesticides were associated with numerous types of cancers, including the brain, pancreatic, lymphoma, myeloma, colon, testicular and soft tissue sarcoma.

\section{Tomato}

Tomato (S. Iycopersicum L.) belongs to the family Solanaceae is commonly grown throughout the globe and typically for the red fruit that is rich in lycopene. Tomato was originated in South America and popularly consumed by a large population in India. There are several diseases that commonly infest tomatoes are various forms of mildew, blight, nematodes and viruses etc. Table 2 describes the pesticide residues in tomato

Table 1. Maximum Residue Limit (MRL) of pesticide residues in vegetables $(\mathrm{mg} / \mathrm{kg})$

\begin{tabular}{lll}
\hline Pesticides & $\begin{array}{l}\text { MRL }(\mathrm{mg} / \mathrm{Kg}) \\
\text { in Tomato }\end{array}$ & $\begin{array}{l}\text { MRL (mg/Kg) } \\
\text { in Capsicum }\end{array}$ \\
\hline Acephate & 0.02 & 0.02 \\
Chlorpyrifos & 0.5 & 0.5 \\
Cyfluthrin- $\beta$ & 3.0 & 2.0 \\
Cyhalothrin-g & 0.2 & 0.2 \\
Cypermethrin & 0.2 & 0.2 \\
Deltamethrin & 0.3 & 0.3 \\
Dichlorvos (DDVP) & 0.2 & 0.2 \\
Fenvalerate & 1 & 0.05 \\
Monocrotophos & $\mathrm{NA}$ & $\mathrm{NA}$ \\
Phorate & 0.024 & 0.024 \\
\hline NA: Not available for the vegetables analysed
\end{tabular}


samples and insecticides standard BDL (Below detection limit) value and range of residues. The results indicated that acephate, cyfluthrin- $\beta$, deltamethrin, dichlorvos, fenvalerate, monocrotophos and phorate concentration were higher than MRL (Maximum residue limit) values. Seven out of ten pesticides were detected and chlorpyrifos, cyhalothrin-g and cypermethrin were not shown any accumulation. Although acephate, cyfluthrin- $\beta$, deltamethrin, dichlorvos, fenvalerate, monocrotophos and phorate were found, the percentage of contamination varied among the pesticides. Acephate was found highest in Pavagada samples (0.346 mg/kg) followed by Kunigal (0.315 mg/kg), Tumakuru $(0.096 \mathrm{mg} / \mathrm{kg}$ ) and lowest in Gubbi $(0.085$ $\mathrm{mg} / \mathrm{kg})$. Cyfluthrin- $\beta$ was recorded in Kunigal $(0.294$ $\mathrm{mg} / \mathrm{kg})$ and Pavagada $(0.281 \mathrm{mg} / \mathrm{kg})$ samples. Deltamethrin was higher in Pavagada samples $(0.296$ $\mathrm{mg} / \mathrm{kg}$ ) and low in Gubbi samples (0.231 mg/kg). Dichlorvos was found highest in Pavagada samples $(0.189 \mathrm{mg} / \mathrm{kg})$ followed by Kunigal $(0.177 \mathrm{mg} / \mathrm{kg})$, Tumakuru $(0.013 \mathrm{mg} / \mathrm{kg}$ ) and lowest in Gubbi $(0.011$ $\mathrm{mg} / \mathrm{kg}$ ) samples. Fenvalerate concentration was higher in Pavagada samples $(0.057 \mathrm{mg} / \mathrm{kg})$ followed by Kunigal $(0.041 \mathrm{mg} / \mathrm{kg})$, Gubbi $(0.036 \mathrm{mg} / \mathrm{kg})$ and lowest in Tumakuru $(0.013 \mathrm{mg} / \mathrm{kg})$ samples. Monocrotophos was found only in Pavagada samples $(0.026 \mathrm{mg} / \mathrm{kg}$ ). Phorate was found in all the four samples and highest in Tumakuru samples $(0.072 \mathrm{mg} / \mathrm{kg})$ followed by Pavagada $(0.045 \mathrm{mg} / \mathrm{kg})$, Gubbi $(0.037 \mathrm{mg} / \mathrm{kg})$ and Kunigal $(0.029 \mathrm{mg} / \mathrm{kg}$ ) samples (Table 2$)$.

The present results are in conformity with the earlier works carried out by Bempah et al. (2011) and Li et al. (2020). They examined pawpaw, imported apples and tomato samples for organochlorine pesticides and detected several organochlorine pesticide residues. To eradicate aphids in the tomato crop endosulfan was used comprehensively in Ghanian agriculture. Salghi et al. (2012) analysed tomato samples from greenhouses in Souss Massa Valley, Morocco and they have detected pesticides in all the samples analysed, three organochlorine pesticides (Dicofol, chlorothalonil and endosulfan) and four pyrethroids pesticides (Bifenithrin, deltamethrin, lambda cyhalothrin and cypermethrin). Acephate pesticides showed the highest residue levels. Irani Mukherjee (2003) identified pesticide residues in seven samples of tomato in and around Delhi, India. All the samples recorded endosulfan, fenvalerate, and acephate in one sample each. Two samples each showed phorate and chlorpyrifos. Maximum pesticides smeared were potent toxins and their rigorous use posed potential hazards to human's livestock and the environment (Ngowi et al., 2007). Sah et al., (2018) reported that cypermethrin and chlorpyrifos residues were above MRL in okra, brinjal and cabbage samples, while endosulfan and quinalphos were found in cauliflower samples in Bihar, India. Nishant and
Upadhyay (2016) observed chlorpyrifos, monocrotophos, endosulfan, DDT and lindane pesticides were observed preliminarily in tomato vegetables in India. From the present study, it was observed that some tomato samples exceeded the MRL. According to farmer's perceptions in the study areas in the Tumakuru district, red spider mites and bollworms were the major pests of tomatoes. There is a considerable increase in red spider mite incidence in all four taluks of Tumakuru district. It may be due to the lack of awareness on pesticides as farmers applied insecticides not recommended for vegetable pest control.

\section{Capsicum}

Capsicum (C. annuum L.) belongs to the family Solanaceae. Table 3 describes the pesticide residues in capsicum samples and insecticides standard BDL value and range of residues. Results detected seven pesticides viz., acephate, chlorpyrifos, cyfluthrin- $\beta$, deltamethrin, dichlorvos, fenvalerate and phorate out of ten pesticides and their concentrations were higher than MRL values and cyhalothrin-g, cypermethrin and monocrotophos were not shown any accumulation. Although acephate, chlorpyrifos, cyfluthrin- $\beta$, deltamethrin, dichlorvos, fenvalerate and phorate were found to present in capsicum samples, the percentage of contamination varied from one pesticide to another. Acephate found highest in Tumkur samples $(0.333 \mathrm{mg} /$ $\mathrm{kg}$ ) followed by Kunigal $(0.325 \mathrm{mg} / \mathrm{kg})$, Pavagada $(0.324 \mathrm{mg} / \mathrm{kg}$ ) and lowest in Gubbi (0.032 mg/kg). Chlorpyrifos was found highest in Kunigal samples (0.153 mg/kg), Pavagada (0.152 mg/kg), Tumkur samples $(0.151 \mathrm{mg} / \mathrm{kg})$ followed by Gubbi $(0.015 \mathrm{mg} /$ $\mathrm{kg})$. Cyfluthrin- $\beta$ was found in Tumkur $(0.045 \mathrm{mg} / \mathrm{kg})$ and Pavagada $(0.042 \mathrm{mg} / \mathrm{kg})$ samples. Deltamethrin was found high in Pavagada samples $(0.381 \mathrm{mg} / \mathrm{kg})$ followed by Tumkur $(0.321 \mathrm{mg} / \mathrm{kg})$, Kunigal $(0.295 \mathrm{mg} /$ $\mathrm{kg}$ ) and low in Gubbi samples (0.251 $\mathrm{mg} / \mathrm{kg})$. Dichlorvos was found only in Pavagada samples (0.042 $\mathrm{mg} / \mathrm{kg}$ ) and lowest in Tumkur samples $(0.041 \mathrm{mg} / \mathrm{kg})$. Fenvalerate concentration is also found high in Pavagada samples $(0.168 \mathrm{mg} / \mathrm{kg})$ followed by Tumkur $(0.123 \mathrm{mg} / \mathrm{kg})$, Gubbi $(0.121 \mathrm{mg} / \mathrm{kg})$ and lowest in Kunigal samples $(0.035 \mathrm{mg} / \mathrm{kg})$. Phorate found in all the four sampling places and found highest in Pavagada samples $(0.089 \mathrm{mg} / \mathrm{kg})$ followed by Tumkur $(0.066 \mathrm{mg} /$ $\mathrm{kg})$, Kunigal $(0.057 \mathrm{mg} / \mathrm{kg})$ and lowest in Gubbi $(0.046$ $\mathrm{mg} / \mathrm{kg}$ ) samples. Capsicum samples analyzed for the pesticide residues revealed that all samples were contaminated with acephate (100\%), chlorpyrifos (100 $\%)$, deltamethrin (100\%), fenvalerate (100\%) and phorate $(100 \%)$ and two were contaminated with cyfluthrin- $\beta$ (50\%) and dichlorvos (50 \%) (Table 3).

Chlorpyrifos level was found below the detection limit in the samples. Golge et al. (2018) observed that 


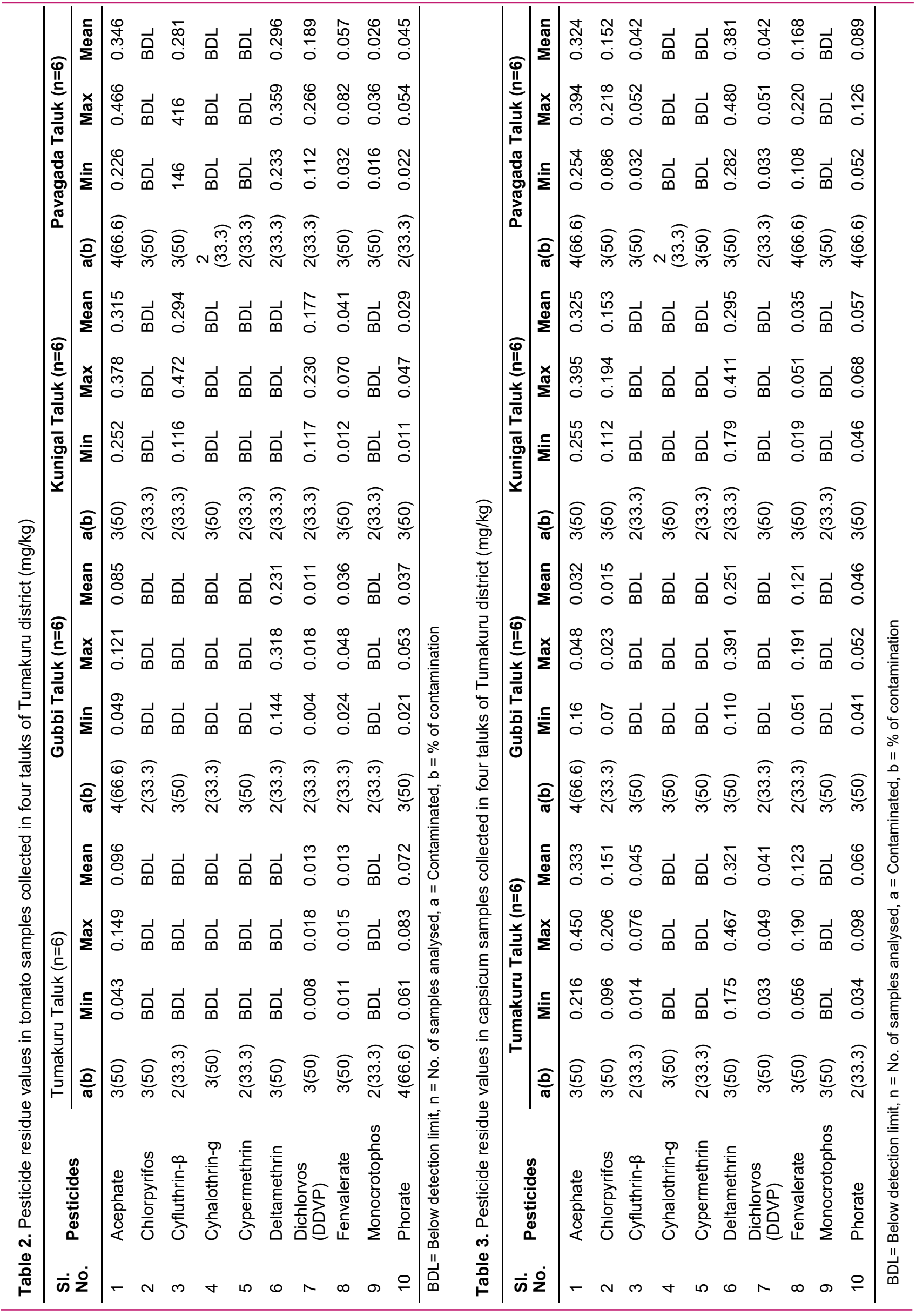


propamocarb and chlorpyrifos were mainly responsible for vulnerabilities manifestation in green pepper and cucumber. Loughlin et al. (2018) reported that insecticide chlorpyrifos was in maximum frequency in vegetables and fruits tested. Pesticides like chlorpyrifos, monocrotophos, endosulfan, DDT and lindane were observed preliminarily in most of the vegetables and okra, brinjal, lettuce, cucumber and tomato vegetables were exceedingly adulterated by pesticides in India (Nishant and Upadhyay, 2016). Swarnam and Velmurugan (2013) experimented on vegetable samples like brinjal, okra, chilli, crucifers and cucurbits for the presence of organochlorines (OC), organophosphorus (OP) and synthetic pyrethroid (SP) compounds; and observed that $34 \%$ of the samples tested had pesticide residues. Owago et al. (2009) observed organochlorine pesticides in vegetables from Deyang and Yanting areas of the Chengdu economic region, Sichuan province, China. They reported endosulfan contamination in a few capsicum samples is high because pests are active in vegetables grown with a high concentration of OCPs. During summer, high temperature volatilized OCPs from soil or vegetation and therefore vegetables secreted evaporating pesticides. Subhash Chandra et al. (2010) determined pesticide residues of Cypermethrin and Chlorpyrifos in vegetables (capsicum and brinjal) purchased from local markets by GC-ECD. Tapped Recoveries of these residues are over $90 \%$, with a coefficient of variation below $5 \%$. The LOD of chlorpyrifos and cypermethrin were $0.005 \mathrm{mg} / \mathrm{kg}$ and LOQ was $0.02 \mathrm{mg} / \mathrm{kg}$. Growers used pesticides to stun bacterial and fungal diseases in capsicum crops. Singh and Gupta (2002) reported that pesticides are commonly detected in capsicum. Chlorpropham was most frequently used and detected in capsicum. They also observed that Azoxystrobin is used as a fungicide to control plant diseases in various crops, including potatoes. All samples were below the Canadian MRL of $30 \mathrm{mg} \mathrm{kg}{ }^{-1}$. Quintero et al. (2008) reported that capsicum was contaminated with OCPs metamidophos (31.3\%). Zhu et al. (2014) reported that capsicum samples showed fenitrothion and malathion insecticides with the mean concentration of 31.0 and $28.6 \mathrm{ppb}$, respectively. No chlorinated insecticide or nitrogen-containing halogenated fungicides were detected.

\section{Conclusion}

The pesticide residue analysis on two vegetables (Tomato and Capsicum) using GC-ECD did not indicate the presence of pesticide residues in almost all the samples examined. The only handful of samples showed their presence. There are many reasons for the accumulation of pesticides in fruits and vegetables.
Farmers have been spraying the pesticide to combat pests and diseases and increase the yield of the crop for several years. Protracted use of pesticides will encourage pest confrontation every time when high amounts are applied. The present study provides favourable evidence on pesticide residue pollution in tomato and capsicum vegetables that helps protect the obstructed environment in the Tumakuru district. Further study on a greater measure should be conducted on vegetables to regulate the pesticide residues condition.

\section{Conflict of interest}

The authors declare that they have no conflict of interest.

\section{REFERENCES}

1. Abhilash, P.C. \& Singh, N. (2009). Pesticide use and application: an Indian scenario. Journal of Hazardous Materials, 165(1-3), 1-12. doi:10.1016/j.jhazm at.2008.1 0.061

2. Beena Kumari. (2008). Effects of house hold processing on reduction of pesticide residues in vegetables. ARPN Journal of Agricultural and Biological Science, 3(4), 46-51.

3. Beena Kumari., Madan, V.K., Singh, J., Singh, S. \& Kathpal, T.S. (2004). Monitoring of pesticide contamination of farmgate vegetables from Hisar. Environmental Monitoring and Assessment, 90(1-3), 65-71. doi:10.1023/B:EM AS.0000003566.63111.f6

4. Bempah, C.K. \& Donkor, A.K. (2011). Pesticide residues in fruits at the market level in Accra Metropolis, Ghana, a preliminary study. Environmental Monitoring and Assessment, 175(1-4), 551-561. doi:10.1007/s10661-0101550-0

5. Bempah, C.K., Donkor, A.K., Yeboah, P.O. \& Dubey, B. (2011). A preliminary assessment of consumer's exposure to organochlorine pesticides in fruits and vegetables and the potential health risk in Accra Metropolis, Ghana. Food Chemistry, 128(4), 1058-1065. doi:10.1016/j.foodch em.2011.04.013

6. Borgert, C.J., Lakind, J.S. \& Witorsch, R.J. (2003). A critical review of methods for comparing estrogenic activity of endogenous and exogenous chemicals in human milk and infant formula. Environmental Health Perspectives, 111(8), 1020-1036. doi:10.1289/ehp.6023

7. Codex Alimentarius Commission. (2017). Pesticide residues in food and feed. Plant Production and Protection Division. Available online: http://www.fao.org/fao-whocodexalimentarius/standards/pestres/en

8. Damalas, C.A. \& Eleftherohorinos, I.G. (2011). Pesticide Exposure, Safety Issues and Risk Assessment Indicators. International Journal of Environmental Research and Public Health, 8(12), 1402-1419.

9. Di Muccio, A., Cicero, A.M., Ausili, A. \& Di Muccio, S. (2006). Chapter-20. Determination of organophosphorus pesticide residues in vegetable oils by single-step multicartridge extraction and clean up and by gas chromatography with flame photometric detector. From, Methods in Biotechnology, Vol. 19, Pesticide Protocols. 
(Ed. Vidal J.L.M. \& Frenich, A.G.) @ Humana Press Inc., Totowa, NJ. pp.263-271.

10. Directorate of Plant Protection, Quarantine \& Storage (2018). Ministry of Agriculture \& Farmers Welfare, Government of India retrieved from http:// ppqs.gov.in/ divisions/pesticides-monitoring-documentation

11. Europian Commission (2012). EU MRLs in View of the First Establishment of Annex II to Regulation (EC) N. 396/2005. (2012). Available online: http://ec.europa.eu/ food/plant/protection/pesticides/pesticide_res_annex_ii.xls

12. Falodun, A., Siraj, R. \& Choudhary, M.I. (2009). GC-MS analysis of insecticidal leaf essential oil of Pyrenacantha staudtii Hutch and Dalz (Icacinaceae). Tropical Journal of Pharmaceutical Research, 8(2), 139-143. doi:10.4314/ tjpr.v8i2.7

13. Fardous, Z., Islam, M.N., Hoque, S.M., Chowdhury, M.A.Z. \& Rahman, M.A. (2007). Determination of some selected pesticide residues in tomato from different locations of Bangladesh. International Journal of Sustainable Agricultural Technology, 3, 4-7.

14. Food and Agriculture Organization / World Health Organization (2004). Food Standards Programme. In Proceedings of Codex Alimentarius Commission. Twenty-Seventh Session, Geneva, Switzerland. pp.1-103.

15. Gill, J.P.S., Bedi, J.S., Singh, R., Fairoze, M.N., Hazarika, R.A., Gaurav, A., Satpathy, S.K., Chauhan, A.S., Lindahl, J., Grace, D., Kumar, A. \& Kakkar, M. (2020). Pesticide residues in peri-urban bovine milk from India and risk assessment: A multicenter study. Scientific Reports, 10:8054. doi:10.1038/s41598-020-65030-z

16. Golge, O., Hepsang, F. \& Kabak, B. (2018). Health risk assessment of selected pesticide residues in green pepper and cucumber. Food and Chemical Toxicology, 121, 51-64. doi:10.1016/j.fct.2018.08.027

17. Indira Devi, P., Tomas, J. \& Raju, R.K. (2017). Pesticide consumption in India: A spatiotemporal analysis. Agricultural Economics Research Review, 30, 163-172.

18. Irani Mukherjee. (2003). Pesticide residues in vegetables in and around Delhi. Environmental Monitoring and Assessment, 86(3), 265-271. doi:10.1023/A:102405742 0937

19. Jayaraj, R., Megha, P. \& Sreedev, P. (2016). Organochlorine pesticides, their toxic effects on living organisms and their fate in the environment. Interdisciplinary Toxicology, 9(34), 90-100. doi:10.1515/intox-2016-0012

20. Kolani, L., Mawussi, G. \& Sanda, K. (2016). Assessment of organochlorine pesticide residues in vegetable samples from some agricultural areas in Togo. American Journal of Analytical Chemistry, 7, 332-341.doi:10.4236/ajac.20 16.74031

21. Kostik, V., Angelovska, B., Petreska, E.K. \& Bauer, B. (2014). Determination of pesticide residues in plant-based foods from the Republic of Macedonia. Journal of Food and Nutrition Science, 2(4), 124-129.

22. Kumar, D. \& Reddy, D.L. (2017). High pesticide use in India: Health implications. Health Action, pp. 7-12. http:// www.pan-india.org/wpcontent/uploads/2017/08/Highpesticide-use-in-India-health-Implications_Health-ActionAugust-2017-1.pdf.

23. Li, S., Yu, P., Ceng Zhou, C., Tong, L., Li, D., Yu, Z. \& Zhao, Y. (2020). Analysis of pesticide residues in commercially available chenpi using a modified
QuEChERS method and GC-MS/MS determination. 10(1), 60-69. doi:10.1016/j.jpha.2019.01.005

24. Loughlin, T.M.M., Peluso, M.L., Etchegoyen, M.A., Alonso, L.L., Castro, M.C., Percudani, M.C. \& Marino, D.J.G. (2018). Pesticide residues in fruits and vegetables of the argentine domestic market: Occurrence and quality. Food Control, 93, 129-138. doi:10.1016/j.foodcont.20 18.05.041

25. Mnif,W., Hassine, A.I.H., Bouaziz, A., Bartegi, A., Thomas, O. \& Roig, B. (2011). Effect of endocrine disruptor pesticides: A review. International Journal of Environmental Research and Public Health, 8, 2265-2303. doi:10.3390/ijerph8062265

26. Ngowi, A.V., Mbise, T.J., ljani, A.S.M. \& London, L. (2007). Pesticides use by smallholder farmers in vegetable production in Northern Tanzania. Crop Protection, 26(11), 1617-1624. doi:10.1016/j.cropro.2007.01.008

27. Nishant, N. \& Upadhyay, R. (2016). Presence of pesticide residue in vegetable crops: A review. Agricultural Reviews, 37(3), 173-185. doi: 10.18805/ag.v37i3.3533

28. Owago, O.J., Shihua Q.I., Li, X.X., Yuan, Z. \& Sylvie, M.A. (2009). Residues of organochlorine pesticides in vegetables from Deyang and Yanting areas of the Chengdu economic region, Sichuan province, China. Journal of American Science, 5(4), 91-100. doi:10.7537/ marsjas050409.13

29. Quintero, A., Caselles, M.J., Ettiene, J., De Colmenares, N.G., Ramirez, T. \& Medina, D. (2008). Monitoring of organophosphorus pesticide residues in vegetables of agricultural area in Venezuela. Bulletin of Environmental Contamination and Toxicology, 81(4), 393-396. doi:10.1007/s00128-008-9511-9

30. Rahman, M.A., Chowdhury, A.Z., Moniruzzaman, M., Gan, S.H., Islam, M.N., Fardous, Z. \& Alam, M.K. (2012). Pesticide residues in tobacco leaves from the Kushtia district in Bangladesh. Bulletin of Environmental Contamination and Toxicology, 89, 658-663.

31. Rauh, V.A., .Garcia, W.E., .Whyatt, R.M., Megan K.Horton, M.K., Dana B.Barr, D.B. \& Louis, E.D. (2015). Prenatal exposure to the organophosphate pesticide chlorpyrifos and childhood tremor. Neoro Toxicology, 51, 80-86. doi:10.1016/j.neuro.2015.09.004

32. Sah, S.B., Gupta, R.N., Kumar, M., Mandal, S.K., Saha, T. \& Singh, S.P. (2018). Pesticide residues from farm gate vegetable samples of vegetables in Bihar. International Journal of Current Microbiology and Applied Science, Sp. Issue 7, 4090-4096.

33. Salghi, R., Luis, G., Rubio, C., Hormatallah, A., Bazzi, L., Gutierrez, A.J. \& Hardisson, A. (2012). Pesticide residues in tomatoes from green houses in Souss Massa Valley, Morocco. Bulletin of Environmental Contamination and Toxicology, 88(3), 358-361. doi:10.1007/s00128-011-0503 $-9$

34. Schreinemachers, P. \& Tipraqsa, P. (2012). Agricultural pesticides and land use intensification in high, middle and low income countries. Food Policy, 37(6), 616-626. doi:10.1016/j.foodpol.2012.06.003

35. Schreinemachers, P., Sefa, V.A., Heng, C.H., Dung, P.T.M., Praneetvatakul, S. \& Srinivasan, R. (2015). Safe and sustainable crop protection in Southeast Asia: Status, challenges and policy options. Environmental Science \& Policy, 54, 357-366. doi:10.1016/j.envsci.2015.07.017 
36. Shammi, M., Sultana, A., Hasan, N., Rahman, Md. M., Islam, Md. S., Bodrud-Doza, Md. \& Uddin Md. K. (2020). Pesticide exposures towards health and environmental hazard in Bangladesh: A case study on farmers' perception. Journal of the Saudi Society of Agricultural Sciences, 19, 161-173. doi:10.1016/j.jssas.2018.08.005

37. Sharma, A., Kumar, V., Shahzad, B., Tanveer, M., Sidhu, G.P.S., Handa, N., Kohli, S.K., Yadav, P., Bali, A.S., Parihar, R.D., Dar, O,I., Singh, K., Jasrotia, S., Bakshi, P., Ramakrishnan, M., Kumar, S., Bhardwaj, R. \& Thukral, A.K. (2019a). Worldwide pesticide usage and its impacts on ecosystem. SN Applied Sciences, 1(11), Article No.1446. doi:10.1007/s42452-019-1485-1

38. Sharma, A., Kumar, V., Thukral, A. \& Bhardwaj, R. (2019b). Responses of plants to pesticide toxicity: An overview. Planta Daninha, 37, e019184291 doi:10.1590/ S0100-83582019370100065

39. Sharma, B.M., Bharat, G.K., Tayal, S., Nizzetto, L., Cupr, P. \& Larssen, T. (2014). Environment and human exposure to persistent organic pollutants (POPs) in India: A systematic review of recent and historical data. Environmental International, 66, 48-64. doi:10.1016/ j.envint.20 14.01.022

40. Singh, B. \& Gupta, A. (2002). Monitoring of pesticide residues in farmgate and market samples of vegetables in a semiarid, irrigated area. Bulletin of Environmental Contamination and Toxicology, 68(5), 747-751. doi:10.10 07/s001280317

41. Standardization Administration of China (2008). Fresh fruits and vegetables-sampling. GB/T 8855-2008. The Standardization Administration of China: Beijing, China. pp. 1-8.

42. Subhash Chandra., Mahindrakar, A.N. \& Shinde, L.P. (2010). Determination of Cypermethrin and Chlorpyrifos in Vegetables by GC-ECD. International Journal of ChemTech Research, 2(2), 908-911.

43. Swarnam, T.P. \& Velmurugan, A. (2013). Pesticide residues in vegetable samples from the Andaman Islands, India. Environmental Monitoring and Assessment, 185(7), 6119-6127. doi:10.1007/s10661-012-3012-3
44. Tekel, J. \& Hatrik, S. (1996). Pesticide residue analysis in plant material by chromatographic methods: clean-up procedures and selective detectors. Journal of Chromatography A. 754(1-2), 397-410. doi:10.1016/ S0021-9673(96)00489-X

45. Thurman, E.M., Fany, Y., Zavitsanos, P. \& Zweigenbaum, J.A. (2008). Multiresidue analysis of 100 pesticides in food samples by LC/Triple Quadruple Mass Spectrometry. Agilent Technologies Publication, pp.5989-5469.

46. United States Environmental Protection Agency (2000) Test Methods for Evaluating Solid Waste. $3^{\text {rd }}$ Edition, EPA SW-846, Update VI - Chapter 4: Organic Analytes, USEPA, Washington DC. pp.1-22.

47. Velmurugan, G., Venkatesh Babu, D.D. \& Ramasamy, S. (2013). Prolonged monocrotophos intake induces cardiac oxidative stress and myocardial damage in rats. Toxicology, 307, 103-108. doi:10.1016/j.tox.2012.11.022

48. Wang, H.S., Sthiannopkao, S., Du, J., Chen, Z.J., Kim, K.W., Yasin, M.S.M., Hashim, J.H., Wong, C.K.C. \& Wong, M.H. (2011). Daily intake and human risk assessment of organochlorine pesticides (OCPs) based on Cambodian market basket data. Journal of Hazardous Materials, 192, 1441-1449. doi:10.1016/j.jhazmat.2011.0 6.062

49. Yadav, I.C., Devi, N.L., Syed, J.H., Cheng, Z., Li, J., Zhang, G. \& Jones K.C. (2015). Current status of persistent organic pesticides residues in air, water, and soil, and their possible effect on neighbouring countries: a comprehensive review of India. Science of the Total Environment, 511, 123-137. doi:10.1016/j.scitotenv.2014.1 2.041

50. Yilmaz, H. (2015). Farm level analysis of pesticide use in sweet cherry (Prunus avium L.) growing in West Mediterranean region of Turkey. Acta Scientiarum Polonorum Hortorum Cultus, 14(3), 115-129.

51. Zhu, Y.Z., Zhao, M.A., Feng, Y.N., \& Kim J.H. (2014). Multiresidue method for the determination of 227 pesticides in hot pepper (Capsicum annuum L.) by liquid chromatography with tandem mass spectrometry. Journal of Separation Science, 37(20), 2947-2954. doi:10.1002/ jssc. 201400536 